\title{
ANALISIS KEBERLANJUTAN PERKEBUNAN KARET DI PULAU SARAK KABUPATEN KAMPAR RIAU
}

\author{
Shorea Khaswarina dan Eliza \\ Jurusan/Program Studi Agribisnis Fakultas Pertanian Universitas Riau \\ E-mail: shoreakhaswarina@yahoo.co.id
}

\begin{abstract}
ABSTRAK. Usaha perkebunan karet rakyat di Pulau Sarak Kabupaten Kampar masih menghadapi banyak kendala. Tujuan penelitian untuk mengatasi kendala tersebut yaitu menganalisis keberlanjutan sistem usahatani karet di Kabupaten Kampar, Provinsi Riau. Metode penelitian adalah survei. Hasil penelitian adalah tingkat keberlanjutan (Ikb) usahatani karet di Kabupaten, secara ekonomi cukup baik dan secara sosial dapat diterima oleh masyarakat, secara ekologis tidak berbahaya bagi lingkungan. Dimensi sosial lebih dominan dalam menentukan keberlanjutan dibandingkan dimensi ekonomi dan lingkungan. Faktor-faktor yang rentan terhadap keberlanjutan usahatani karet di Kabupaten Kampar adalah stabilitas harga hasil pertanian pada saat panen (dimensi ekonomi), pH air di lahan pertanian dan fluktuasi debit air pada lahan petani (dimensi lingkungan).
\end{abstract}

Kata kunci: indeks keberlanjutan karet, dimensi sosial, ekonomi, lingkungan.

\section{SUSTAINABILITY ANALISYS OF RUBBER PLANTATION IN SARAK ISLAND DISTRIC KAMPAR RIAU}

\begin{abstract}
The smallholder rubber plantation business in Sarak Island Kampar Regency still faces many obstacles. The objective of this research is to analyze the sustainability of rubber farming system in Kampar regency, Riau Province. The research method is survey. The result of this research is the level of sustainability (Ikb) of rubber farming in Regency, economically good enough and socially acceptable by society, ecologically not harmful to the environment. Social dimensions are more dominant in determining sustainability than economic and environmental dimensions. Factors that are susceptible to sustainability of rubber farming in Kampar regency are price stability of agricultural produce at harvest time (economic dimension), water pH in agricultural land and fluctuation of water debit on farmer's land (environmental dimension).
\end{abstract}

Key words: rubber sustainability index, social dimension, economy, environment

\section{PENDAHULUAN}

Kebijakan pemerintah Indonesia tentang pertanian berkelanjuan telah sesuai dengan konsep dari Food Agricultural Organization (FAO) terkait pembangunan pertanian berkelanjutan. FAO menawarkan mekanisme untuk melaksanakan tindakan nyata menuju pencapaian Pertanian Berkelanjutan dan Pembangunan Pedesaan (Sustainable Agriculture and Rural Development). Demikian pula melalui konferensi tingkat tinggi PBB telah ditekankan pentingnya pertanian berkelanjutan, sehingga memberikan kontribusi terhadap ketahanan pangan dan pengelolaan sumber daya alam (FAO, 2002). Upaya mewujudkan pertanian berkelanjutan, setiap usahatani harus berorientasi pada proses pencapaian produksi yang menguntungkan dan efisien dengan menekankan pada perbaikan manajemen, dan pencegahan penyakit.

Kabupaten Kampar merupakan salah satu sentra produksi karet di Provinsi Riau. Tahun 2013 luas perkebunan karet rakyat di Kabupaten Kampar adalah 92.509 ha dengan produksi 60.714 ton/tahun. Mata pencaharian masyarakat di Kabupaten Kampar sebagian besar adalah petani karet dan sawit. Jumlah petani karet rakyat di Kabupaten Kampar adalah 52.289 Kepala Keluarga (BPS Kabupaten Kampar, 2014). Permasalahan yang dihadapi petani karet adalah harga yang diterima petani sering tidak menentu ada jangka waktu yang tidak dapat diperkirakan. Sesuai data di lapangan harga jual karet ditingkat petani berfluktuasi yaitu pada Bulan April Rp.8.923, Bulan Mei Rp.7.146, Bulan Juni Rp.6.825, Bulan Juli Rp.6.423, Bulan Agustus Rp.7.179, Bulan Sepetember Rp.6.498. Kondisi ini jelas akan mempengaruhi keberlanjutan usahatani karet yaitu menguntungkan atau tidak dari aspek usaha tani (aspek ekonomi), tidak menurun kualitasnya (aspek lingkungan) serta usahatani yang dikembangkan dapat diterima atau diadopsi oleh semua pihak (aspek sosial). Oleh karena itu maka tujuan penelitian ini adalah menganalisis tingkat keberlanjutan dari aspek sosial, ekonomi dan lingkungan.

\section{METODE}

Penelitian ini dilakukan di Pulau Sarak Kabupaten Kampar dengan lama penelitian sekitar 8(delapan) bulan. Pemilihan sampel responden pada penelitian ini dilakukan melalui dua tahap, yaitu pemilihan kecamatan dilakukan secara sengaja (purposive sampling) dengan pertimbangan sebagai sentra produksi karet di Kabupaten Kampar, yaitu Kecamatan Kampar. Selanjutnya dari kecamatan dipilih satu desa. Agar responden petani dapat mewakili luas penguasaan lahan, maka pada penelitian ini responden telah didistribusikan secara proporsional terhadap penguasaan lahan tersebut.

$$
\mathrm{n}=\text {--------- }
$$


Keterangan:

$\mathrm{n}=$ Jumlah responden.

$\mathrm{N}=$ Jumlah populasi (kepala keluarga petani).

$\mathrm{e}=$ Galat yang dapat diterima $(10 \%)$.

Populasi di daerah penelitian pada Pulau Sarak Kecamatan Kampar terdiri dari 173 KK. Dengan tingkat presisi sebesar 10\% maka jumlah sampel pada penelitian ini sebanyak 40 responden.

Data primer yang telah dikumpulkan selanjutnya diurutkan (batching), dilakukan proses coding, tabulasi dan analisis. Analisis diskriptif digunakan untuk mengidentifikasi profil dan permasalahan usaha perkebunan karet di Pulau Sarak Kabupaten Kampar. Sedangkan data sekunder diperoleh dari berbagai sumber referensi dan instansi terkait yang mendukung penelitian ini.

Analisis data dalam penelitian ini adalah menilai indeks dan status keberlanjutan perkebunan karet di Pulau Sarak Kabupaten Kampar dan menilai indeks status keberlanjutan masing-masing dimensi (produksi, kelembagaan, dan sosial ekonomi) pada perkebunan karet di Kabupaten Kampar menggunakan teknik ordinasi Rap-Rubber melalui metoda Multi Dimensional Scaling $(M D S)$. Nilai indek dilihat dan status keberlanjutan yang diperoleh dibandingkan dengan Tabel 1.

Tabel 1.Nilai indeks dan status keberlanjutan

\begin{tabular}{ccll}
\hline No & Nilai Indeks & Kategori & \multicolumn{1}{c}{ Keterangan } \\
\hline 1 & $0,00-24,99$ & Buruk & Tidak berkelanjutan \\
2 & $25,00-49,99$ & Kurang & Kurang berkelanjutan \\
3 & $50,00-74,99$ & Cukup & Cukup berkelanjutan \\
4 & $75,00-100,00$ & Baik & Berkelanjutan \\
\hline
\end{tabular}

Sumber : Kavanagh dan Pitcher, 2004

Mengidentifikasi atribut/peubah yang sensitif berpengaruh pada keberlanjutan perkebunan karet di Kabupaten Kampar menggunakan Leverage Analysis untuk menentukan peubah yang sensitif mempengaruhi keberlanjutan perkebunan karet. Atribut sensitif yang diperoleh dari hasil Leverage Analysis terlihat pada perubahan Roof Mean Square (RMS) ordinasi pada sumbu X. Semakin besar perubahan RMS, maka semakin sensitif peranan atribut tersebut terhadap peningkatan status keberlanjutan. Analisis Monte Carlo merupakan metode simulasi untuk mengevaluasi dampak kesalahan acak/galat (random error) dalam analisis statistik yang dilakukan terhadap seluruh dimensi (Kavanagh dan Pitcher, 2004).

\section{HASIL DAN PEMBAHASAN}

Perkebunan karet di Pulau Sarak Kabupaten Kampar merupakan perkebunan karet terluas di Provinsi Riau. Data sosial ekonomi responden petani terdiri atas dimensi sosial, yaitu 10 atribut meliputi: persepsi terhadap pengelolaan, keterlibatan kelompok tani, langkah pelestarian, cara awal pembukaan lahan, perubahan proses produksi, kearifan lokal, kebijakan pemerintah, penyuluhan, lembaga penyuluh, penerapan teknologi.

Dimensi ekonomi, terdiri dari 12 atribut meliputi pendapatan, penggunaan tenaga kerja dalam keluarga, harga, harga ojol, panen, luas lahan, status lahan, pemasaran, fluktuasi harga, ketersediaan pestisida, ketersediaan pupuk, pemupukan. Dimensi lingkungan, terdiri dari 12 atribut meliputi : kegiatan pengendalian erosi, penurunan permukaan tanah, pencemaran tanah, dampak pestisida, penggunaan pestisida, dampak pupuk, $\mathrm{pH}$ air, sistem pengairan, pengaruh dekomposisi, frekuensi kebakaran, komoditi sampingan, pengetahuan petani terhadap tanaman tanaman penutup tanah (Legum Cover Crop/LCC). Penggunaan tanaman ini merupakan pengetahuan lokal petani yang merupakan salah satu bentuk dari pemahaman terhadap pertanian berkelanjutan. Sesuai dengan pendapat Hijjang P, et al (2014), pengetahuan lokal diaplikasikan dalam setiap kegiatan pertanian mulai dari penentuan musim dan pemilihan bibit hingga pasca panen dan hasil produksi.

Potensi keberlanjutan usahatani karet di Pulau Sarak, didasarkan pada indikator nilai indeks keberlanjutan. Hasil analisis Rap-Rubber multidimensi dengan menggunakan metoda MDS menghasilkan nilai IKB-Rubber di Desa Pulai Rambai Kabupaten Kampar sebesar 54,34 $(50,01-75,00)$ termasuk kategori cukup berkelanjutan. Indeks Keberlanjutan perkebunan karet dimensi ekonomi sebesar 61,5 dan dimensi lingkungan sebesar 62,44 artinya masing-masing dimensi berada pada skala sustainibilitas 0-100, termasuk kategori status cukup berkelanjutan. Nilai Ikb-Rubber untuk dimensi sosial sebesar 39,08 pada skala sustainabilitas 25,0050,01 , termasuk kategori status kurang berkelanjutan, seperti terlihat pada Gambar 1. Berdasarkan nilai tersebut, yang paling dominan berkontribusi terhadap nilai indeks keberlanjutan usahatani tanaman karet di Pulau Sarak Kabupaten Kampar secara berurutan adalah dimensi ekologi/lingkungan, ekonomi dan sosial.

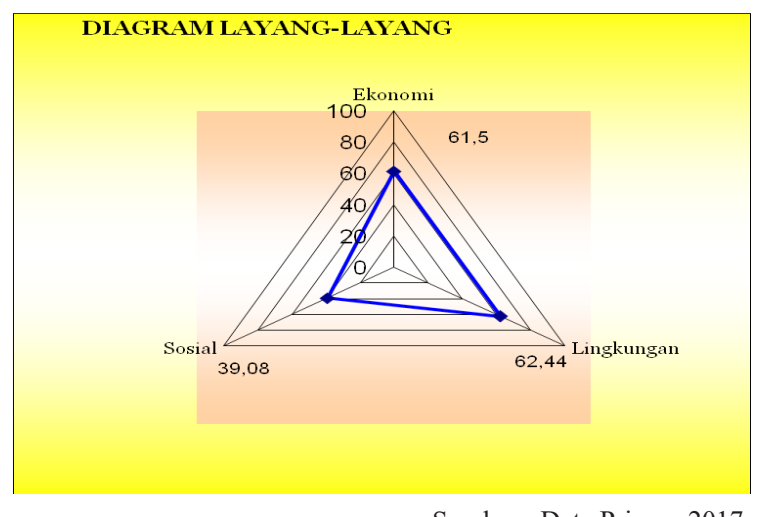

Gambar 1. Kontribusi setiap dimensi tanaman karet di Pulau Sarak. 
Berdasarkan kajian ini terbukti bahwa dalam jangka panjang usahatani tanaman karet tidak sekedar mentargetkan keuntungan maksimal dalam jangka pendek, tetapi usahatani dimaksud harus mampu mempertahankan dan melestarikan sumber daya alam, yaitu melalui sistem pertanian berkelanjutan. Upaya untuk mempertahankan potensi keberlanjutan tersebut, ada beberapa pendekatan yang dapat dilakukan, yaitu (1) proses produksi mengarah pada penggunaan hayati dan ramah lingkungan; (2) pola pertanian yang dikembangkan harus dapat menjamin investasi dalam bentuk tenaga kerja dan biaya lainnya dengan hasil produksi atau outputnya dapat mencukupi kebutuhan keluarga secara layak, atau dapat diartikan bahwa keberlanjutan usahatani harus mampu meminimalkan atau bahkan menghilangkan biaya eksternal dalam proses produksi.

Mengevaluasi dimensi ekologi, diidentifikasi 12 atribut atau faktor yang mempengaruhi tingkat keberlanjutan usahatani karet. Berdasarkan hasil analisis leverage keberlanjutan usahatani karet dimensi ekologi seperti yang terlihat pada Gambar 2 diketahui bahwa dari 11 atribut yang dianalisis ada 4 atribut yang sensitif mempengaruhi keberlanjutan perkebunan karet yaitu: (1) $\mathrm{pH}$ air, (2) penggunaan pestisida, (3) pencemaran tanah, (4) pengetahuan tanaman LCC. Dengan demikian atributatribut tersebut perlu mendapat perhatian dan dikelola dengan baik agar nilai indeks keberlanjutan ketersediaan karet dimensi ekologi ini meningkat di masa yang akan datang. Atribut yang paling sensitif yang mempengaruhi keberlanjutan perkebunan karet dari dimensi ekologi adalah pH air yang ditunjukkan oleh skala 5 .

$\mathrm{pH}$ air sangat erat pengaruhnya terhadap $\mathrm{pH}$ tanah. $\mathrm{pH}$ tanah sangat menentukan pertumbuhan dan produktivitas tanaman, umumnya $\mathrm{pH}$ tanah yang optimal adalah 5,6 - 6,0. Sedangkan fluktuasi air berkaitan dengan tinggi muka air tanah yang dipengaruhi oleh kanal (parit). Tinggi muka air tanah akan memperkecil risiko kebakaran pada lahan gambut dan memudahkan pertumbuhan tanaman (Santoso, 2012). pH air di lahan usahatani karet dan fluktuasi debit air serta elevasi muka air sangat mempengaruhi produktivitas dan kelestarian lingkungan.

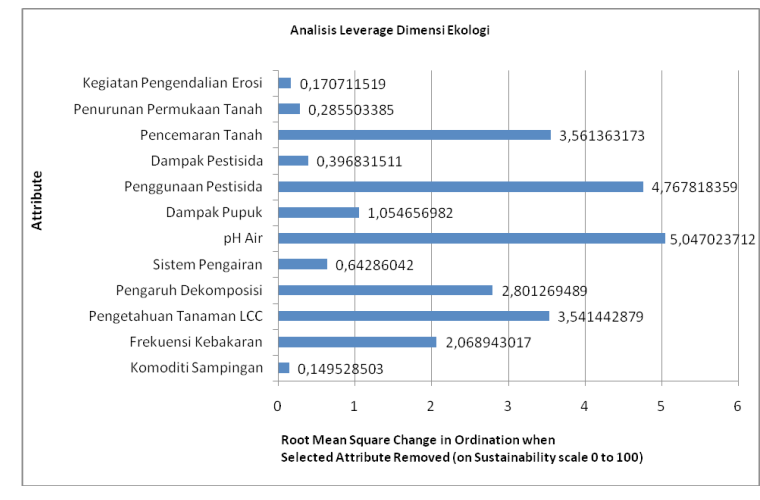

Sumber : Data Primer, 2017

Gambar 2. Analisis sensitifitas dimesi ekologi, usaha tani tanaman karet di Pulau Sarak.
Dimensi ekonomi yang dievaluasi dan diidentifikasi ada sebanyak 11 atribut atau faktor yang mempengaruhi tingkat keberlanjutan usahatani karet di Pulau Sarak Kabupaten Kampar. Hasil analisis sensitifitas (leverage analysis), terdapat 4 atribut atau faktor yang sensitif mempengaruhi keberlanjutan usahatani status lahan, harga ojol, fluktuasi harga dan luas lahan (skala 3). Dari pengamatan dilapangan, ternyata harga jual produk petani sangat berfluktuasi dan cenderung nilai tukarnya rendah terutama pada saat panen, hal ini yang menjadi permasalahan di tingkat petani.

Pada umumnya usahatani karet bagi petani di Pulau Sarak Kecamatan Kampar adalah mata pencaharian utama mereka. Sebagian besar (75\%) lahan pertanian di Pulau Sarak dimiliki oleh penduduk setempat, yang diperoleh melalui pembelian, pembagian dan warisan keluarga. Lahan milik petani setempat, sepenuhnya dipelihara dan dikelola oleh petani pemilik masingmasing beserta keluarganya. Status lahan dan luas lahan yang terbatas merupakan permasalahan utama bagi petani karet, sehingga usahatani yang dilakukan petani belum dapat menjadi sumber pendapatan utama yang dapat menopang seluruh kebutuhan petani dan keluarga. Realita di lapangan, sebagian besar petani hanya konsentrasi pada saat panen khususnya panen karet.

Harga hasil pertanian dalam jangka pendek, cenderung berfluktuatif atau tidak stabil. Ketidakstabilan tersebutbisa disebabkan oleh permintaan dan penawaran terhadap barang pertanian yang sifatnya tidak elastis. Beberapa faktor yang menyebabkan penawaran terhadap barang pertanian tidak elastis, adalah : produk pertanian umumnya musiman, kapasitas memproduksi sektor pertanian cenderung untuk mencapai tingkat yang tinggi dan tidak terpengaruh oleh perubahan permintaan, beberapa jenis tanaman memerlukan waktu bertahuntahun sebelum hasilnya dapat dipanen. Irawan, (2007 )mengemukakan bahwa fluktuasi harga komoditas pertanian pada dasarnya akibat ketidakseimbangan antara kuantitas pasokan dan permintaan yang dibutuhkan konsumen tidak seimbang. Jika terjadi kelebihan pasokan maka harga komoditas akan turun, dan sebaliknya jika terjadi kekurangan pasokan. Dalam proses pembentukan harga tersebut, petani dan pedagang memiliki peranan penting dalam mengatur volume penjualan yang selayaknya disesuaikan dengan kebutuhan konsumen.

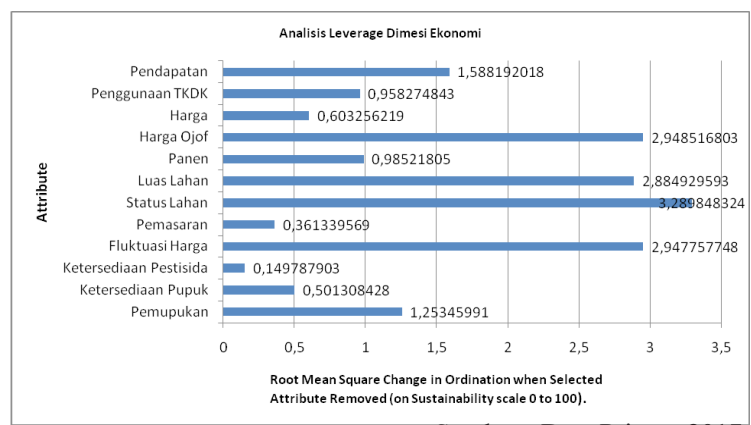

Gambar 2. Analisis sensitifitas dimensi ekologi usahatani karet di Pulau Sarak. 
Dimensi sosial yang diidentifikasi 10 atribut atau faktor yang mempengaruhi tingkat keberlanjutan usahatani karet di Pulau Sarak Kabupaten Kampar. Hasil analisis sensitifitas (leverage analysis), di Pulau Sarak terdapat 5 atribut yang sensitif mempengaruhi keberlanjutan usahatani karet. Faktor sensitif tersebut adalah penerapan teknologi, kearifan lokal, cara pembukaan lahan, perubahan proses produksi dan kebijakan pemerintah. Tingkat sensitifitasnya berada pada skala lebih besar dari 5, artinya atribut-atribut tersebut sangat mempengaruhi keberlanjutan usahatani karet di Pulau Sarak.

Penerapan teknologi yang diamati didalam penelitian ini adalah bagaimana tingkat adopsi petani karet terhadap penerapan teknologi budidaya tanaman karet yang sesuai dengan anjuran terdiri atas 9 komponen yang keseluruhannya diadopsi dalam usahatani para petani. 9 komponen tersebut adalah penggunaan varietas unggul, pengolahan tanah/lahan, penanaman, pemupukan, pemeliharaan, pengendalian hama dan penyakit, pengairan, panen dan pasca panen. Teknologi pertanian merupakan piranti teknis di bidang pertanian yang dikembangkan dari ilmu pengetahuan untuk mempermudah, mempercepat, meningkatkan, mengarahkan, membina, dan membimbing usahatani sesuai dengan sasaraan yang hendak dicapai. Lebih jauh lagi tujuan penerapan teknologi menurut SK Mentan No 9/1984 adalah peningkatan produksi, pendapatan, kesempatan kerja, devisa, dan kelestarian sumberdaya alam (Rachmawati, E, et al, 2008). Menurut Kasryno, F (1998) untuk wilayah perluasan baru diperlukan teknologi tepat guna (appropiate teknology) untuk meningkatkan efisiensi dan nilai tambah dengan bertumpu pada keterbatasan, tenaga kerja, kapital dan sumberdaya pertanian lainnya.

Kearifan lokal yang diamati dalam penelitian ini adalah seluruh proses produksi dalam usahatani karet yaitu mulai dari pembukaan lahan, pembakaran lahan, penggunaan peralatan, larangan-larangan dalam pembukaan lahan, pembibitan, penanaman, pemeliharaan, penyadapan sampai proses pengolahan hasil panen (ojol). Hasil penelitian menunjukkan bahwa kondisi kearifan lokal dahulu dengan kondisi pada saat penelitian adalah tidak sama. Artinya kearifan lokal yang dahulu ada, tidak lagi dilakukan.

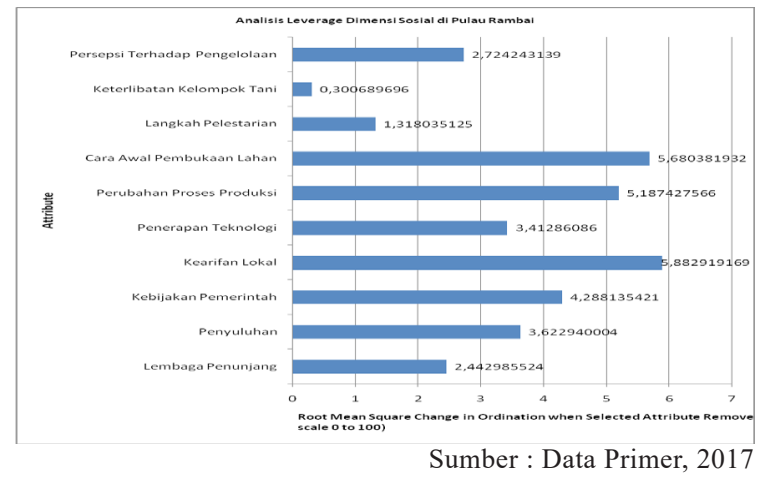

Gambar 3. Analisis sensitifitas dimesi sosial, usahatani tanaman karet di Pulau Sarak.
Cara pembukaan lahan yang dilakukan petani karet di lokasi penelitian dengan menebang pohonpohon yang besar menggunakan alat mesin singso dan menggunakan kampak dan parang untuk pohon-pohon yang tidak besar. Selain itu, membakar masih dilakukan, tetapi dengan skala dan intensitas yang kecil. Meskipun petani karet sudah memahami peraturan pemerintah tentang kebijakan larangan membakar dalam membuka hutan dan lahan untuk kegiatan bercocok tanam sesuai dengan Undang-Undang No. 4 Tahun 2001. Namun cara pembukaan lahan dengan cara membakar dipengaruhi oleh keterbatasan tenaga kerja dan modal yang dimiliki serta cara ini diannggap lebih mudah sehingga menimbulkan dampak negatif terhadap lingkungan. Petani umumnya kesulitan dalam menentukan tahapan pembukaan dan pembakaran lahan, karena dibatasi oleh aturan atau larangan pembakaran lahan untuk menghindari kabut asap. Petani tidak diperbolehkan membakar lahan. Pengalaman saat ini, menunjukkan bahwa jika hujan langsung turun biasanya dalam curah hujan yang tinggi yaitu pada bulan Desember, sehingga mengakibatkan penyiapan lahan menjadi kurang optimal dan waktu tanam menjadi tidak menentu. Sedangkan perubahan produksi dipengaruhi oleh perubahan iklim, petani umumnya mengetahui isu perubahan iklim tersebut dari media massa (radio dan televisi). Perubahan iklim ini menyebabkan kuantitas dan kualitas hasil panen karet petani menjadi rendah.

\section{SIMPULAN}

Tingkat keberlanjutan usahatani tanaman karet di Pulau Sarak yang didasarkan pada nilai indeks keberlanjutan multidimensi di Kecamatan Kampar Kabupaten Kampar Riau menunjukkan skala cukup berkelanjutan dengan nilai indeks 54,34 artinya usahatani karet yang dikembangkan petani di Pulau Sarak berdasarkan pertimbangan ekonomi, sosial dan aspek ekologi/lingkungan, cukup berkelanjutan. Dengan kata lain bahwa usahatani karet tersebut memberi manfaat secara ekonomi, secara sosial dapat diterima masyarakat, dan secara ekologis tidak merusak lingkungan. Dimensi sosial lebih dominan dalam menentukan keberlanjutan usahatani dibanding dengan dimensi ekonomi dan lingkungan. Faktor yang peka mempengaruhi keberlanjutan perkebunan karet di Pulau Sarak di kaji dari dimensi sosial adalah kearifan lokal. Menurut Hijjang P, et al (2014) untuk membangun petani yang berjiwa agroecopreneur dan arif lingkungan diperlukan akumulasi pengetahuan lokal dan kreatifitas petani, baik yang bersumber dari tradisi lokal maupun yang dari luar secara selektif dalam situasi dan kondisi yang kondusif melibatkan secara aktif semua unsur stakeholder. Kestabilan harga hasil petani pada saat panen (dimensi ekonomi), $\mathrm{pH}$ air di lahan usahatani dan fluktuasi debit air di lahan petani (dimensi lingkungan/ ekologi). 
Implikasi kebijakan dari kajian ini adalah: (a) meningkatkan dan menjaga kearifan lokal yang berwawasan lingkungan, (b) Implementasi nyata dari kebijakan pemerintah dalam mengatasi masalah harga panen yang tidak membantu petani, (c) langkah nyata meningkatkan $\mathrm{pH}$ air dengan pengelolaan sistem tata air sehingga debit air menjadi stabil.

\section{DAFTAR PUSTAKA}

BPS Kabupaten Kampar. (2014). Kampar Dalam Angka 2013. Badan Pusat Statistik Kabupaten Kampar. Bangkinang.

[FAO] Food Agriculture Organitation, (2002). Good agricultural practices. Second Edition. FAO.

Irawan, M.A., (2007). Glukosa dan Metabolisme Energi. Sport Science Brief. 1 (6):12-5.

Kasryno F. (1998). Pemikiran peningkatan daya saing komoditas pertanian melalui pemanfaatan mekanisasi pertanian yang ramah lingkungan. Pusat Studi Ekonomi-Badan Litbang Pertanian. Departemen Pertanian. Bogor.
Kavanagh P, Pitcher TJ. (2004). Implementing microsoft excel software for rapfish: A technique for the rapid appraisal of fisheries status. University of British Columbia Fisheries Centre Research Report 12 (2004).

Hijjang, P., Lampe, M. dan Basir, M. (2014). Aneka ragam pengetahuan lokal dan kreatifitas petani yang mendukung agroecopreneuer ramah lingkungan di sulawesi selatan. Jurusan Antropologi Fakultas Ilmu Sosial dan Ilmu Politik Universitas Hasanuddin. Jurnal Sosiohumaniora, 16 (2): 143148.

Rachmawati, E. dan Djuwendah, E. (2008). Tingkat penerapan teknologi produksi kedelai (glysine max (l) merril) di kecamatan conggeang dan buahdua kabupaten sumedang. Jurnal Sosiohumaniora, 10 (1): Hal 43-57.

Santoso, S. (2012). Panduan Lengkap SPSS Versi 20. Jakarta: PT Elex Media Komputind 